\title{
Tailoring B cell depletion therapy in MS according to memory B cell monitoring
}

\author{
Giovanni Novi, MD, Francesca Bovis, PhD, Sabrina Fabbri, MD, Francesco Tazza, MD, Paola Gazzola, MD, \\ Ilaria Maietta, Daniela Currò, MD, Nicolò Bruschi, MD, Luca Roccatagliata, MD, PhD, Giacomo Boffa, MD, \\ Caterina Lapucci, MD, Giampaola Pesce, PhD, Maria Cellerino, MD, Claudio Solaro, MD, Alice Laroni, MD, PhD, \\ Elisabetta Capello, MD, Gianluigi Mancardi, MD, Mariapia Sormani, PhD, Matilde Inglese, MD, PhD, * and \\ Antonio Uccelli, MD*
}

Neurol Neuroimmunol Neuroinflamm 2020;7:e845. doi:10.1212/NXI.0000000000000845

\section{Abstract}

\section{Objective}

We wanted to evaluate efficacy on inflammatory parameters of rituximab (RTX)-personalized reinfusion scheme using a memory B cell-based treatment regimen.

\section{Methods}

This is a prospective, uncontrolled, open-label study including patients with MS treated with RTX in 2 Italian MS units. All patients were treated with RTX induction, followed by maintenance infusion at the dosage of $375 \mathrm{mg} / \mathrm{m}^{2}$, according to memory B cell repopulation $(0.05 \%$ of peripheral-blood mononuclear cells [PBMCs] for the first 2 years, $0.1 \%$ of PBMC for the third year). MS activity was assessed as clinical or MRI activity.

\section{Results}

One hundred two patients were included in the analysis. Mean follow-up was 2.40 years (range $0.57-7.15$ years). The annualized relapse rate (ARR) was 0.67 in the year before RTX start and decreased to 0.01 in the 3 years after RTX initiation (global ARR). The proportion of patient with MS activity (i.e., relapse or MRI activity) was $63.16 \%$ in the year before RTX start and decreased to $8.7 \%$ (0-6 months), 1.3\% (6-12 months), 0\% (12-24 months), and 0\% (24-36 months). Annualized RTX infusion rates were 1.67 (95\% confidence interval [CI]: 1.43-1.94), 0.76 (95\% CI: $0.58-0.98$ ), and 0.78 (95\% CI: $0.52-1.12$ ) for the first 3 years after RTX initiation, respectively. Patients were reinfused with a mean infusion interval of 367 days (range 181-839 days).

\section{Conclusion}

The results of this study show that the memory B cell-based RTX reinfusion protocol is able to reduce the mean number of RTX reinfusions with persistent reduction of disease activity.

\section{Classification of evidence}

This study provides Class IV evidence that for patients with MS, a memory B cell-based RTX reinfusion protocol can reduce the mean number of RTX reinfusions with persistent reduction of disease activity.

\author{
Correspondence \\ Dr. Novi \\ giovanninovi@gmail.com
}

MORE ONLINE

$\rightarrow$ Class of Evidence

Criteria for rating

therapeutic and diagnostic studies

NPub.org/coe

\footnotetext{
*Both last coauthors equally contributed to the manuscript.

From the Department of Neuroscience (G.N.), Ospedale Policlinico San Martino-IRCCS; Department of Health Sciences (DISSAL) (F.B., I.M., L.R., M.S.), University of Genova, Italy; Ospedale A. Micone (S.F., P.G.), Genova; Department of Neuroscience (F.T., N.B., G.B., C.L., M.C., A.L., E.C., G.M.), Rehabilitation, Ophthalmology, Genetics, Maternal and Child Health (DINOGMI), University of Genova; Ospedale Policlinico San Martino-IRCCS (F.T., N.B., L.R., A.L., E.C., M.S., M.I., A.U.), Genova, Italy; Ospedale San Paolo (D.C.), Savona; Autoimmunity Laboratory DiMI (G.P.), University of Genova, Italy; Monsignor Luigi Novarese Rehabilitation Center (C.S.), Moncrivello, Vercelli; Istituti Clinici Scientifici Maugeri (G.M.), IRCCS, Pavia; and Department of Neuroscience (M.I., A.U.), Rehabilitation, Ophthalmology, Genetics, Maternal and Child Health (DINOGMI) and Center of Excellence for Biomedical Research (CEBR), University of Genova, Italy.
}

Go to Neurology.org/NN for full disclosures. Funding information is provided at the end of the article.

The Article Processing Charge was funded by the authors.

This is an open access article distributed under the terms of the Creative Commons Attribution-NonCommercial-NoDerivatives License 4.0 (CC BY-NC-ND), which permits downloading and sharing the work provided it is properly cited. The work cannot be changed in any way or used commercially without permission from the journal. 


\section{Glossary}

ARIR = annualized reinfusion rate; $\mathbf{A R R}=$ annualized relapse rate $\mathbf{C I}=$ confidence interval; $\mathbf{E D S S}=$ expanded disability status scale; $\mathbf{m A b}=$ monoclonal antibody; $\mathbf{O C R}=$ ocrelizumab; $\mathbf{P B M C}=$ peripheral blood mononuclear cell; $\mathbf{P P}=$ primary progressive; $\mathbf{R R}=$ relapsing-remitting; $\mathbf{R T X}=$ rituximab; $\mathbf{S E}=$ standard error; $\mathbf{S P}$ = secondary progressive.

The MS therapeutic field has been recently widened by the approval of ocrelizumab (OCR) treatment as the first antiCD20-depleting monoclonal antibody $(\mathrm{mAb}) .{ }^{1}$ Rituximab (RTX), a first-generation anti-CD20 $\mathrm{mAb}$, has also been adopted as an off-label treatment in MS, ${ }^{2,3}$ and it is currently used as standard of care therapy in some European countries. ${ }^{4}$ The standard treatment regimen of anti-CD20 mAbs usually consists of an "induction" phase, followed by regular fixed maintenance reinfusions (usually every 6 months). However, despite being a more practical approach in the daily practice, the fixed doses regimen could represent an overtreatment because $B$ cells could be still depleted before each subsequent retreatment dose, as B cell immune reconstitution after B cell depletion ranges from 27 to 125 weeks with a median of 72 weeks. ${ }^{5}$ In addition, no data support the fact that resurgence (and/or normalization) of $\mathrm{CD} 19^{+} \mathrm{B}$ cells is strictly associated with an inflammatory activity (i.e., clinical relapse or MRI activity).

Furthermore, a subgroup of B cells called memory B cells (characterized by CD19 and CD27 co-expressions) have been recently implied as a putative target of many MS-approved treatments (including CD20-depleting mAbs). ${ }^{6}$ Peripherical blood memory B cell dosage has been extensively adopted in neuromyelitis optica to tailor RTX redosing with consistent results. $^{7-10}$

Consequently, evaluating peripheral blood memory B cells resurgence to tailor RTX retreatment in MS might optimize RTX redosing, reducing the number of infusions, possibly maintaining consistent efficacy on MRI and relapse activity, and potentially reducing risks of adverse events. To test our hypothesis, we conducted a pilot study in $2 \mathrm{MS}$ centers in Italy to assess efficacy on inflammatory parameters (i.e., MRI activity and clinical relapses) of memory B cells-tailored RTX redosing in patients with MS.

\section{Methods}

We designed a proof-of-concept, uncontrolled, single-arm, open-label, prospective study where we enrolled patients with MS who were referred to our clinic and were treated, with an off-label indication, with RTX, since 2012. Database was locked in November 2019.

The primary research question was to evaluate efficacy on inflammatory parameters of RTX-personalized reinfusion scheme using a memory B cell-based treatment regimen.

\section{Standard protocol approvals, registrations, and patient consents}

The local ethic committee approved treatment regimen and data collection, and patients signed written informed consent before treatment initiation.

\section{Patients}

Patients were treated with RTX with two 1-g infusions 15 days apart as loading doses. Patients were then followed up quarterly with memory B cell evaluation (assessed as $\mathrm{CD} 19^{+}$and $\mathrm{CD} 27^{+}$cells). MRI assessment was performed within 6 months of RTX initiation, followed by additional scans at the end of each treatment year.

\section{Treatment}

Patients were reinfused with $375 \mathrm{mg} / \mathrm{m}^{2}$ RTX when the percentage of memory B cells exceeded the predefined reinfusion cutoff: $0.05 \%$ of peripheral blood mononuclear cells (PBMC) for the first 2 years and $0.1 \%$ of PBMC for the third year with subsequent doubling for each year of treatment (maximum cutoff at the 7 th year of treatment of $1.6 \%$ of PBMC). A year-by-year increase in the threshold for reinfusion was adopted to further reduce the number of RTX reinfusions with each year of treatment.

\section{Statistical analysis}

The Annualized relapse rate (ARR), defined as the total number of relapses divided by the total number of patient years, pre- and post-RTX start, and the annualized reinfusion rate (ARIR) after RTX initiation were compared by mixedeffect negative binomial models accounting for the repeated measures analysis, with $p$-values adjusted for multiple testing by the Bonferroni correction. SAS 9.3 (Institute Inc., Cary, NC) and R software (version 3.5.0) were used for the computation.

\section{Data availability}

Raw data are available on appropriate request.

\section{Results}

One hundred two patients were enrolled in the study: 34 patients $(33.33 \%)$ had a relapsing-remitting (RR) phenotype, $29(28.43 \%)$ a primary progressive (PP) phenotype, and 39 (38.24\%) a secondary progressive (SP) phenotype. Eightytwo percent of RRMS individuals and 52\% of progressive patients (regardless of a primary or secondary phenotype) displayed disease activity at MRI carried out in the year before RTX start. Complete demographic analysis is reported in 
table. At database lock, the patient mean follow-up was 2.40 years (range $0.57-7.15$ years). The annualized relapse rate was 0.43 (95\% confidence interval [CI]: $0.35-0.53$ ) in the 2 years before RTX initiation and increased to 0.67 (95\% CI: $0.52-0.84)$ in the year before RTX initiation. As expected, ARR was dramatically reduced on RTX initiation to 0.01 (95\% CI: 0.001-0.04) in the first year, 0.01 (95\% CI: $0.001-0.06)$ in the second year, and 0.00 (95\% CI: 0.00-0.10) in the third year, with a 3-year global ARR of 0.01 (95\% CI: $0.002-0.03)(p<0.0001)$ (figure 1).

Of 60 patients (63.16\%) with MRI evidence of activity (either $\mathrm{Gd}+$ enhancing lesions or new enlarging $\mathrm{T} 2 /$ fluid attenuated inversion recovery lesions) in the year before RTX initiation, 28 patients $(26.32 \%)$ had a RR phenotype, whereas the remaining 32 (33.68\%) had a progressive phenotype.

Table Baseline characteristics for 102 patients with MS treated with RTX, grouped by MS subtype

\begin{tabular}{|c|c|c|c|c|}
\hline & All & $\mathbf{R R}$ & PP & SP \\
\hline & $N=102$ & $\mathbf{N}=\mathbf{3 4}$ & $N=29$ & $\mathbf{N}=39$ \\
\hline Age at MS onset, y, mean (SD) & $30.90(10.25)$ & $28.71(7.38)$ & $39.29(9.98)$ & $26.58(9.02)$ \\
\hline Gender (female), n (\%) & $67(65.69)$ & $21(61.76)$ & $18(62.07)$ & $28(71.79)$ \\
\hline MS duration, $y$, mean (SD) & $11.29(8.61)$ & $7.68(6.97)$ & $6.63(5.47)$ & $17.92(7.71)$ \\
\hline Comorbidity, n (\%) & $37(36.27)$ & $15(44.12)$ & $8(27.59)$ & $14(35.90)$ \\
\hline Autoimmune comorbidity, $\mathrm{n}(\%)$ & $9(8.82)$ & $3(8.82)$ & $2(6.90)$ & $4(10.26)$ \\
\hline EDSS 6 mo pre-RTX, median (range) & $5(0-8.5)$ & $2.5(0-7)$ & $5(1.5-6.5)$ & $6(1.5-8.5)$ \\
\hline EDSS at RTX start, median (range) & $5(1-8.5)$ & $3(1.0-7.5)$ & $5(1.5-6.5)$ & $6.5(3-8.5)$ \\
\hline No. relapse 2 y pre-RTX, median (range) & $1(0-4)$ & $1.5(0-4)$ & $0(0-3)$ & $0(0-2)$ \\
\hline No. relapse 1 y pre-RTX, median (range) & $0(0-3)$ & $1(0-3)$ & $0(0-2)$ & $0(0-2)$ \\
\hline Presence of active MRI 1 y pre-RTX, n (\%) & $60 / 95(63.16)$ & $28(82.35)$ & $12 / 23(52.17)$ & $20 / 38(52.63$ \\
\hline Presence of spinal lesions 1 y pre-RTX, n (\%) & $37 / 90(41.11)$ & $23(67.65)$ & $7 / 18(38.89)$ & $7 / 38(18.42)$ \\
\hline Naïve patients, $\mathrm{n}(\%)$ & $18(17.65)$ & 7 (20.59) & $9(31.03)$ & $2(5.13)$ \\
\hline Previous treatments, median (range) & $2(0-7)$ & $2(1-5)$ & $1(1-4)$ & $3(1-7)$ \\
\hline Last DMT before RTX, n (\%) & $84(82.35)$ & $27(79.41)$ & $20(68.97)$ & $37(94.87)$ \\
\hline Cyclophosphamide & $6(7.14)$ & $1(3.70)$ & $2(10.00)$ & $3(8.11)$ \\
\hline Daclizumab & $1(1.19)$ & $1(3.70)$ & $0(0.00)$ & $0(0.00)$ \\
\hline Dimethyl fumarate & $5(5.95)$ & $2(7.41)$ & $3(15.00)$ & $0(0.00)$ \\
\hline Fingolimod & $30(35.71)$ & $10(37.04)$ & $3(15.00)$ & $17(49.95)$ \\
\hline Glatiramer acetate & $8(9.52)$ & $3(11.11)$ & $1(5.00)$ & $4(10.81)$ \\
\hline Interferons & $11(13.10)$ & $4(14.81)$ & $3(15.00)$ & $4(10.81)$ \\
\hline Natalizumab & $11(13.10)$ & $3(11.11)$ & $2(10.00)$ & $6(16.22)$ \\
\hline Teriflunomide & $2(2.38)$ & $1(3.70)$ & $1(5.00)$ & $0(0.00)$ \\
\hline Other & $10(11.90)$ & $2(7.41)$ & $5(25.00)$ & $3(8.11)$ \\
\hline Reasons for changing to RTX, $\mathrm{n}(\%)$ & $84(82.35)$ & $27(79.41)$ & $20(68.97)$ & $37(94.87)$ \\
\hline Inefficacy & $54(64.29)$ & $19(70.37)$ & $15(75.00)$ & $20(54.05)$ \\
\hline Intolerance/adverse event & $11(13.10)$ & $2(7.41)$ & $4(20.00)$ & $5(13.51)$ \\
\hline $\mathrm{JCV}+$ & $8(9.52)$ & $2(7.41)$ & $1(5.00)$ & $5(13.51)$ \\
\hline Pregnancy & $1(1.19)$ & $1(3.70)$ & $0(0.00)$ & 7 (18.92) \\
\hline Other & $10(11.90)$ & $3(11.11)$ & $0(0.00)$ & $0(0.00)$ \\
\hline
\end{tabular}

Abbreviations: DMT = disease-modifying treatment; EDSS = expanded disability status scale; JCV+ = positive for John Cunningham virus; PP = primary progressive; RR = relapsing remitting; RTX = rituximab; SP = secondary progressive. 
Figure 1 Trend of annualized relapse rate in the 2 years preceding rituximab treatment and in the 3 years after rituximab initiation

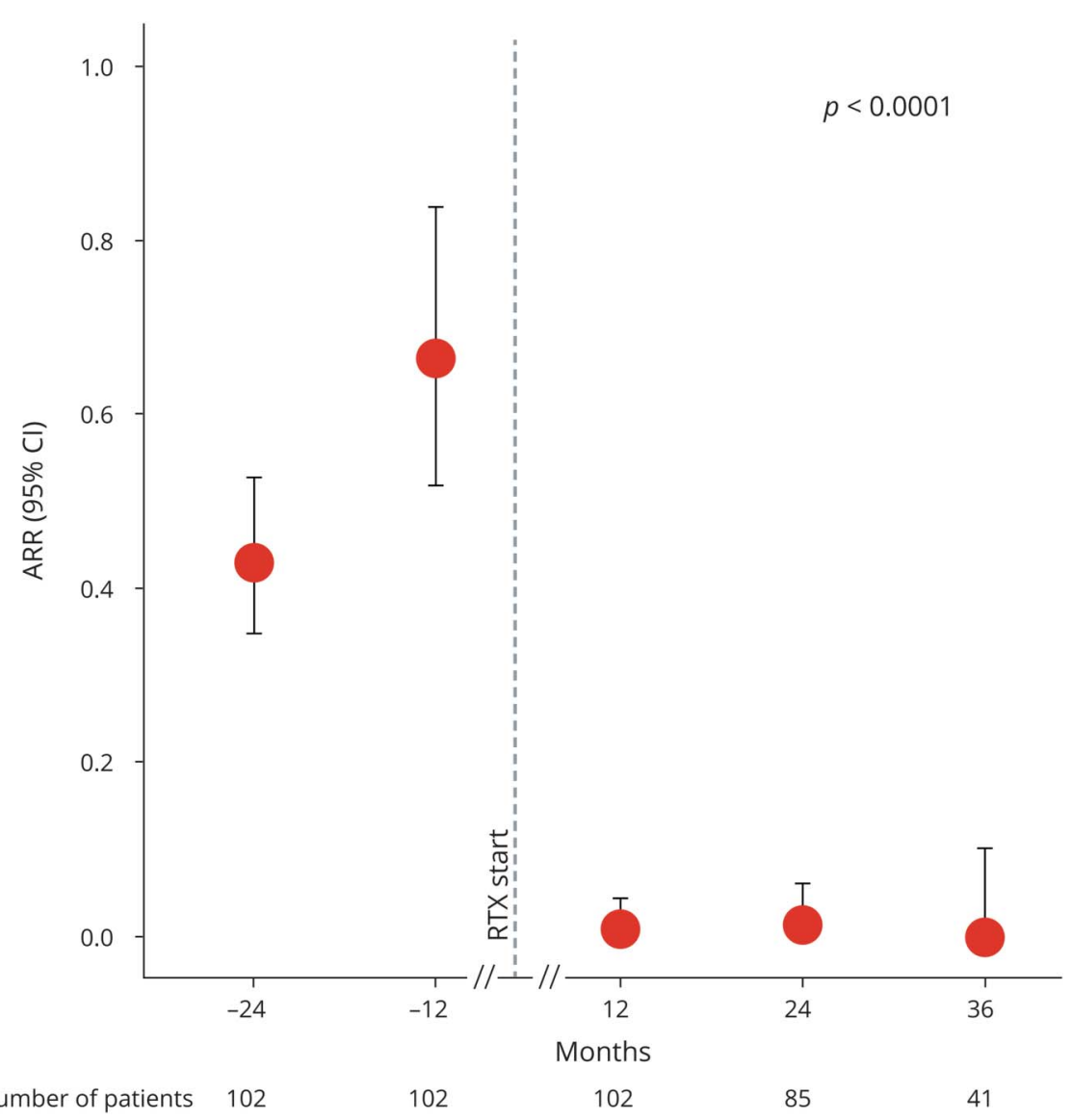

Such a proportion declined to $8.70 \%$ ( $8 / 92$ patients) in the first 6 months after therapy initiation (4 RR patients and 4 progressive patients) and then to $1.28 \%(1 / 78 \mathrm{PP}$ patient) in the subsequent 6 months (till month 12$), 0 \%$ (0/59 patients) in the second year, and $0 \%$ in the third year ( $0 / 32$ patients). To date, none of the patients with a follow-up longer than 3 years experienced relapses or disease activity during the subsequent years of follow-up.

Nine of 102 patients (8.82\%) (4 RR, 4 PP, and 1 SP) had inflammatory activity (defined as relapse and/or MRI activity) during the first 6 months after therapy initiation, probably as a consequence of a carryover activity from previous disease-modifying treatments (mainly natalizumab or fingolimod) and because of delayed onset of RTX maximum efficacy.

Interestingly, ARIR was consistently reduced year by year: during the first year, ARIR was 1.67 (95\% CI: 1.43-1.94), 0.76 (95\% CI: $0.58-0.98)$ in the second year, and 0.78 (95\% CI: $0.52-1.12)$ in the third year $(p<0.0001)$. The results are consistent with those obtained analyzing only the 41 patients who have completed at least 3 years of follow-up: ARIR was 1.75 (95\% CI: 1.38-2.19) in the first year, 0.87 (95\% CI:
$0.62-1.20)$ in the second year, and 0.78 (95\% CI: 0.52-1.12) in the third year (figure 2).

The median number of memory B cells before reinfusions was 2 cells $/ \mathrm{mm}^{3}$ (range $1-53$ cells $/ \mathrm{mm}^{3}$ ) in the first year, 2 cells/ $\mathrm{mm}^{3}$ (range $1-21$ cells $/ \mathrm{mm}^{3}$ ) in the second year, and 3 cells/ $\mathrm{mm}^{3}$ (range $1-18$ cells $/ \mathrm{mm}^{3}$ ) in the third year of treatment.

The median (range) baseline expanded disability status scale (EDSS) score was 3.0 (1.0-7.5) in patients with RRMS, 6.5 (3.0-8.5) in patients with SPMS, and $5.0(1.5-6.5)$ in patients with PPMS. The median time to progression was 1.65 years $(0.38-7.15)$.

The proportion of patients with a 6-month confirmed EDSS progression after 3 years from RTX start was $8.82 \%$ (standard error $[\mathrm{SE}]=0.02)$ in the RRMS group, $17.95 \%(\mathrm{SE}=0.05)$ in the SPMS group, and $48.28 \%(\mathrm{SE}=0.09)$ in the PPMS group.

Patients were reinfused with a mean infusion interval of 367 days (range 181-839 days).

During the follow-up, 14/102 (13.72\%) experimented an infusion-related reaction (IRR), all occurring during the first 3 
Figure 2 Trend of annualized rituximab reinfusion rate in the 3 years after rituximab initiation for the whole population enrolled (blue) and for the 41 patients who have completed at least 3 years of follow-up (red)

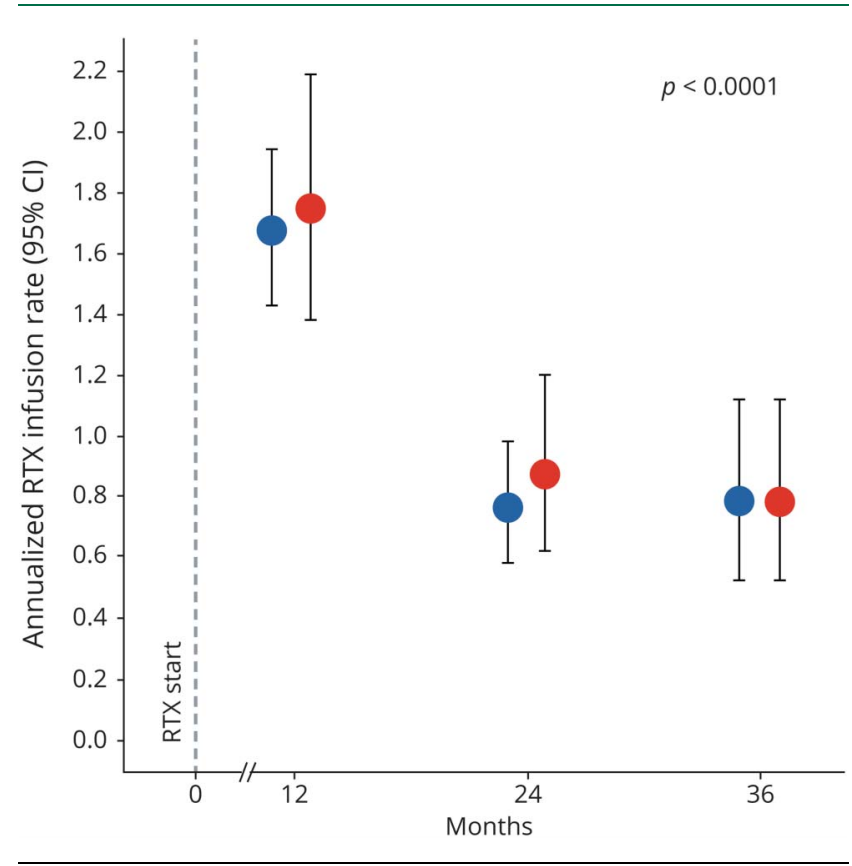

infusions, and 75/102 (73.53\%) patients developed AE and 19 patients developed a serious AE (see supplementary appendix 1, links.lww.com/NXI/A290). At the 2-year follow-up, among patients with known immunoglobulin levels $(n=46)$, hypogammaglobulinemia (immunoglobulin $\mathrm{G}$ levels lower than $5.6 \mathrm{~g} / \mathrm{L}$ ) developed in 2 patients, whereas for 2 patients, it was pre-existent and one patient developed hypogammaglobulinemia after 6 years of treatment. One patient died during the follow-up because of an undifferentiated mediastinal tumor lesion.

\section{Discussion}

In this pilot, uncontrolled study, we show that the RTX reinfusion protocol based on memory $B$ cells might be feasible and able to reduce ARIR and drug dosage, preserving efficacy on inflammatory parameters (i.e., relapses and MRI activity).

This proposed scheme moves toward a personalized medicine approach in MS, a paradigm shift that is much needed in the field, especially considering emerging data on long-term safety of fixed doses reinfusion schemes for CD20-depleting antibodies. ${ }^{11}$ Our protocol might confirm the putative role of memory B cells in MS pathogenesis, addressing relevant questions on the mechanism of action of some diseasemodifying treatments in MS. Notably, we show that, with our reinfusion scheme, RTX reinfusions could be performed less than once per year at the second year of treatment, representing a 50\% reduction in reinfusion rates, compared with classical schemes with a significant saving of drug and subsequent economical advantage possibly arising from the reduction of the yearly infused drug and from the decrement of the use of healthcare system resources.

For patients with progressive MS (either SP or PP), our findings suggest that our regimen could reduce the chance of disability accrual through a reduction in the inflammatory activity. However, similar to other approved CD20depleting therapies (i.e., OCR), it is reasonable to speculate that this treatment regimen will not be able to completely abolish disability progression driven by ongoing neurodegeneration.

The main limit of our study is represented by the lack of a control group that is required for disability progression analysis and is warranted for the comparison of composite outcomes, such as no evidence of disease activity. In addition, a control group is needed to compare the adverse event's occurrence (including hypogammaglobulinemia), although a lower intensity regimen of $\mathrm{B}$ cell depletion might warrant a safer risk profile. To date, many patients completed at least 2 years of treatment without emergence of MS activity, and therefore, it is reasonable that a reinfusion cutoff of $0.05 \%$ memory B cell is safe and potentially applicable to everyday clinical practice.

Finally, we hope that our data might prompt the conduction of randomized clinical trial to assess the efficacy and safety of tailored reinfusion schemes for CD20-depleting mAbs.

\section{Study funding}

No targeted funding reported.

\section{Disclosure}

G. Novi received speaker honoraria from Merck, Novartis, and Roche. F. Bovis reports no disclosures relevant to the manuscript. S. Fabbri reports no disclosures relevant to the manuscript. F. Tazza reports no disclosures relevant to the manuscript. P. Gazzola reports no disclosures relevant to the manuscript. I. Maietta reports no disclosures relevant to the manuscript. D. Currò reports no disclosures relevant to the manuscript. N. Bruschi reports no disclosures relevant to the manuscript. L. Roccatagliata reports no disclosures relevant to the manuscript. G. Boffa reports no disclosures relevant to the manuscript. C. Lapucci reports no disclosures relevant to the manuscript. G. Pesce reports no disclosures relevant to the manuscript. M. Cellerino reports no disclosures relevant to the manuscript. C. Solaro reports no disclosures relevant to the manuscript. A. Laroni received honoraria for speaking by Biogen Idec, Novartis, and Teva; consulting fees by Merck Serono, Sanofi-Genzyme, and Novartis; and funding for travel from Teva, Merck Serono, Biogen, and Novartis. E. Capello reports no disclosures relevant to the manuscript. G. Luigi Mancardi reports no disclosures relevant to the manuscript. M. Pia Sormani received consulting fees from Biogen Idec, Merck Serono, Teva, Genzyme, Roche, Novartis, GeNeuro, 
and Medday. M. Inglese received honoraria or consultation fees from Roche, Biogen, Merck-Serono, Novartis, Genzyme, and research grants from NIH, NMSS, FISM, and Teva Neuroscience. A. Uccelli received honoraria or consultation fees from Biogen, Roche, Teva, Merck-Serono, Genzyme, and Novartis. Go to Neurology.org/NN for full disclosures.

\section{Publication history}

Received by Neurology: Neuroimmunology \& Neuroinflammation January 20, 2020. Accepted in final form June 5, 2020.

\section{Appendix Authors}

\begin{tabular}{|c|c|c|}
\hline Name & Location & Contribution \\
\hline $\begin{array}{l}\text { Giovanni Novi, } \\
\text { MD }\end{array}$ & $\begin{array}{l}\text { University of } \\
\text { Genova, Genova, } \\
\text { Italy }\end{array}$ & $\begin{array}{l}\text { Major role in the acquisition of } \\
\text { data, interpreted the data, design } \\
\text { and conceptualized study, } \\
\text { analyzed the data, and drafted the } \\
\text { manuscript }\end{array}$ \\
\hline $\begin{array}{l}\text { Francesca } \\
\text { Bovis, PhD }\end{array}$ & $\begin{array}{l}\text { University of } \\
\text { Genova, Genova, } \\
\text { Italy }\end{array}$ & $\begin{array}{l}\text { Analyzed the data and revised the } \\
\text { manuscript for intellectual content }\end{array}$ \\
\hline $\begin{array}{l}\text { Sabrina } \\
\text { Fabbri, MD }\end{array}$ & $\begin{array}{l}\text { Antero Micone } \\
\text { Hospital, Genova }\end{array}$ & Major role in acquisition of data \\
\hline $\begin{array}{l}\text { Francesco } \\
\text { Tazza, MD }\end{array}$ & $\begin{array}{l}\text { University of } \\
\text { Genova, Genova, } \\
\text { Italy }\end{array}$ & Major role in acquisition of data \\
\hline $\begin{array}{l}\text { Paola Gazzola, } \\
\text { MD }\end{array}$ & $\begin{array}{l}\text { Antero Micone } \\
\text { Hospital, Genova }\end{array}$ & Major role in acquisition of data \\
\hline Ilaria Maietta & $\begin{array}{l}\text { University of } \\
\text { Genova, Genova, } \\
\text { Italy }\end{array}$ & Analyzed the data \\
\hline $\begin{array}{l}\text { Daniela Currò, } \\
\text { MD }\end{array}$ & $\begin{array}{l}\text { University of } \\
\text { Genova, Genova, } \\
\text { Italy }\end{array}$ & Major role in acquisition of data \\
\hline $\begin{array}{l}\text { Nicolò } \\
\text { Bruschi, MD }\end{array}$ & $\begin{array}{l}\text { University of } \\
\text { Genova, Genova, } \\
\text { Italy }\end{array}$ & Major role in acquisition of data \\
\hline $\begin{array}{l}\text { Luca } \\
\text { Roccatagliata, } \\
\text { MD, PhD }\end{array}$ & $\begin{array}{l}\text { University of } \\
\text { Genova, Genova, } \\
\text { Italy }\end{array}$ & Major role in acquisition of data \\
\hline $\begin{array}{l}\text { Giacomo } \\
\text { Boffa, MD }\end{array}$ & $\begin{array}{l}\text { University of } \\
\text { Genova, Genova, } \\
\text { Italy }\end{array}$ & Major role in acquisition of data \\
\hline $\begin{array}{l}\text { Caterina } \\
\text { Lapucci, MD }\end{array}$ & $\begin{array}{l}\text { University of } \\
\text { Genova, Genova, } \\
\text { Italy }\end{array}$ & Major role in acquisition of data \\
\hline $\begin{array}{l}\text { Giampaola } \\
\text { Pesce, PhD }\end{array}$ & $\begin{array}{l}\text { University of } \\
\text { Genova, Genova, } \\
\text { Italy }\end{array}$ & Major role in acquisition of data \\
\hline
\end{tabular}

Appendix (continued)

\begin{tabular}{|c|c|c|}
\hline Name & Location & Contribution \\
\hline $\begin{array}{l}\text { Maria } \\
\text { Cellerino, MD }\end{array}$ & $\begin{array}{l}\text { University of } \\
\text { Genova, Genova, } \\
\text { Italy }\end{array}$ & Major role in acquisition of data \\
\hline $\begin{array}{l}\text { Claudio } \\
\text { Solaro, MD }\end{array}$ & $\begin{array}{l}\text { Antero Micone } \\
\text { Hospital, Genova }\end{array}$ & Major role in acquisition of data \\
\hline $\begin{array}{l}\text { Alice Laroni, } \\
\text { MD, PhD }\end{array}$ & $\begin{array}{l}\text { University of } \\
\text { Genova, Genova, } \\
\text { Italy }\end{array}$ & Major role in acquisition of data \\
\hline $\begin{array}{l}\text { Elisabetta } \\
\text { Capello, MD }\end{array}$ & $\begin{array}{l}\text { University of } \\
\text { Genova, Genova, } \\
\text { Italy }\end{array}$ & Major role in acquisition of data \\
\hline $\begin{array}{l}\text { Gianluigi } \\
\text { Mancardi, MD, } \\
\text { PhD }\end{array}$ & $\begin{array}{l}\text { University of } \\
\text { Genova, Genova, } \\
\text { Italy }\end{array}$ & Major role in acquisition of data \\
\hline $\begin{array}{l}\text { Mariapia } \\
\text { Sormani, PhD }\end{array}$ & $\begin{array}{l}\text { University of } \\
\text { Genova, Genova, } \\
\text { Italy }\end{array}$ & $\begin{array}{l}\text { Analyzed the data and revised the } \\
\text { manuscript for intellectual content }\end{array}$ \\
\hline $\begin{array}{l}\text { Matilde } \\
\text { Inglese, MD, } \\
\text { PhD }\end{array}$ & $\begin{array}{l}\text { University of } \\
\text { Genova, Genova, } \\
\text { Italy }\end{array}$ & $\begin{array}{l}\text { Analyzed the data and revised the } \\
\text { manuscript for intellectual content }\end{array}$ \\
\hline $\begin{array}{l}\text { Antonio } \\
\text { Uccelli, MD }\end{array}$ & $\begin{array}{l}\text { University of } \\
\text { Genova, Genova, } \\
\text { Italy }\end{array}$ & $\begin{array}{l}\text { Analyzed the data and revised the } \\
\text { manuscript for intellectual content }\end{array}$ \\
\hline
\end{tabular}

\section{References}

1. Hauser SL, Bar-Or A, Comi G, et al. Ocrelizumab versus interferon beta-1a in relapsing multiple sclerosis. New Engl J Med 2017;376:221-234.

2. Salzer J, Svenningsson R, Alping P, et al. Rituximab in multiple sclerosis A retrospective observational study on safety and efficacy. Neurology 2016;87:2074-2081.

3. Zecca C, Bovis F, Novi G, et al. Treatment of multiple sclerosis with rituximab: a multicentric Italian-Swiss experience. Mult Scler J 2019. Epub 2019 Oct 1.

4. Berntsson SG, Kristoffersson A, Boström I, Feresiadou A, Burman J, Landtblom AM. Rapidly increasing off-label use of rituximab in multiple sclerosis in Sweden-outlier or predecessor? Acta Neurol Scand 2018;138:327-331.

5. SmPC Ocrelizumab [Internet]. 2019. Available at: ema.europa.eu/en/documents/ product-information/ocrevus-epar-product-information_en.pdf. Accessed May 28, 2020.

6. Baker D, Marta M, Pryce G, Giovannoni G, Schmierer K. Memory B cells are major targets for effective immunotherapy in relapsing multiple sclerosis. EBioMedicine 2017.

7. Kim SH, Jeong IH, Hyun JW, et al. Treatment outcomes with rituximab in 100 patients with neuromyelitis optica: influence of FCGR3A polymorphisms on the therapeutic response to rituximab. JAMA Neurol 2015;72:989-995.

8. Novi G, Bovis F, Capobianco M, et al. Efficacy of different rituximab therapeutic strategies in patients with neuromyelitis optica spectrum disorders. Mult Scler Relat Disord 2019;36:101430

9. Kim SH, Kim W, Li XF, Jung IJ, Kim HJ. Repeated treatment with rituximab based on the assessment of peripheral circulating memory B cells in patients with relapsing neuromyelitis optica over 2 years. Arch Neurol 2011;68:1412-1420.

10. Kim SH, Hyun JW, Kim HJ. Individualized B cell-targeting therapy for neuromyelitis optica spectrum disorder. Neurochem Int 2019;130:104347.

11. Serum immunoglobulin levels and risk of serious infections in the pivotal Phase III trials of ocrelizumab in multiple sclerosis and their open-label extensions [Internet]. 2019. Available at: medically.roche.com/en/search/pdfviewer.67fblaea-a4a2-41f3 91c4-20c8696215d2.html?cid=slpsxx1909nexxectrims2019. Accessed May 28, 2020. 


\section{Neurology \\ Neuroimmunology \& Neuroinflammation}

\section{Tailoring B cell depletion therapy in MS according to memory B cell monitoring Giovanni Novi, Francesca Bovis, Sabrina Fabbri, et al. \\ Neurol Neuroimmunol Neuroinflamm 2020;7; \\ DOI 10.1212/NXI.0000000000000845}

This information is current as of August 4, 2020

\section{Updated Information \& Services}

References

Citations

Subspecialty Collections

Permissions \& Licensing

Reprints including high resolution figures, can be found at: http://nn.neurology.org/content/7/5/e845.full.html

This article cites 6 articles, 0 of which you can access for free at: http://nn.neurology.org/content/7/5/e845.full.html\#\#ref-list-1

This article has been cited by 2 HighWire-hosted articles: http://nn.neurology.org/content/7/5/e845.full.html\#\#otherarticles

This article, along with others on similar topics, appears in the following collection(s):

All Immunology

http://nn.neurology.org//cgi/collection/all_immunology

Class IV

http://nn.neurology.org//cgi/collection/class_iv

Multiple sclerosis

http://nn.neurology.org//cgi/collection/multiple_sclerosis

Information about reproducing this article in parts (figures,tables) or in its entirety can be found online at:

http://nn.neurology.org/misc/about.xhtml\#permissions

Information about ordering reprints can be found online: http://nn.neurology.org/misc/addir.xhtml\#reprintsus

Neurol Neuroimmunol Neuroinflamm is an official journal of the American Academy of Neurology.

Published since April 2014, it is an open-access, online-only, continuous publication journal. Copyright Copyright $\odot 2020$ The Author(s). Published by Wolters Kluwer Health, Inc. on behalf of the American Academy of Neurology.. All rights reserved. Online ISSN: 2332-7812.

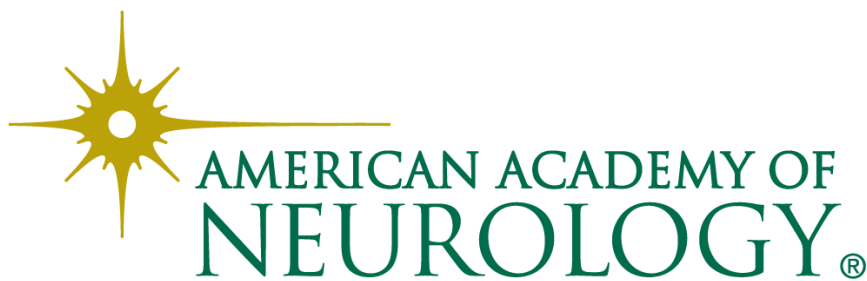

